\title{
Impact of Foliar Spray by Zinc Oxide Nanoparticles on Peanut Pro- duction Under New Valley Conditions
}

\author{
Ali, E.A.; M.T. Said; ${ }^{*}$ M.A. Sayed and M.R. Sonosy \\ Agronomy Department, Faculty of Agriculture, Assiut University, Assiut, 71526, \\ Egypt. \\ *Corresponding author: msayed@aun.edu.eg
}

Received on: $31 / 12 / 2020$

Accepted for publication on: 11/1/2021

\begin{abstract}
Increasing seed and oil yields production of oil crops in reclaimed soils is an important goal of vision Egypt 2030. Therefore, a field experiment was conducted in newly reclaimed sandy soil in Farafra, New valley Governorate, Egypt during the two summer seasons of 2017 and 2018 to examine the impact of $\mathrm{Zn}$ nano-fertilizer foliar spray on peanut production. The field experiment was laid out in a randomized complete block design (RCBD) using a strip plot arrangement with three replications. Zinc oxide nanoparticles concentrations ( 0 as control, 200, 400 and $600 \mathrm{ppm}$ ) were allotted horizontally while, the cultivars NC9, Gregory and Ismailia were a signed vertically. Highly significant differences were observed among zinc oxide nanoparticles ( $\mathrm{ZnO}$ NPs) concentrations for most studied traits in both seasons. Furthermore, peanut cultivars had a significant effect on most studied traits in both seasons. All peanut cultivars showed remarkable positive responses to the spray of zinc nanoparticles. In most cases, an enhancement was observed in most studied traits by increasing the concentration from $200 \mathrm{ppm}$ to $600 \mathrm{ppm}$. Also, NC9 cultivar gave the highest seed yield $(\mathrm{kg} / \mathrm{fed})$ in both seasons, while there were non-significant differences among peanut cultivars for oil yield (kg/fed) but as an average over both seasons, NC9 gave the highest oil yield (kg/fed). Therefore, the findings of this study suggest that NC9 cultivar with spraying by zinc nanoparticles might be a good choice for planting and production under newly reclaimed soils in the Farafra region with other important recommended agronomical practices for such region.
\end{abstract}

Keywords: Peanut, Zn Fertilization, reclaimed sandy soils.

\section{Introduction}

Peanut (Arachis hypogaea L.) is the fourth major oilseeds crop of the world. In 2015, peanut contributed $8.7 \%$ of the total oil seeds production (45 million ton) in the world (Anonymous, 2015). Peanut is an important oilseed crop for vegetable oil production. About two-thirds of total peanut production is crushed for oil and the remaining one-third is used in confectionery products in the world (Arioglu, 2014). In Egypt, peanut production was about 237129 tonnes, which was produced from 65000 hectars with an average yield of $36481 \mathrm{~kg} / \mathrm{ha}$ (FAO, 2018).

Nutrients deficiency is the third most important stress limiting plant productivity worldwide. Peanuts are a sensitive crop of micro-elements deficiency, especially in alkaline and poor sandy soils (Zuo and Zhang 2011). Moreover, $\mathrm{Zn}$ is most deficient in soils and it does not throw away the deficiency symptoms, unlike iron, 
that is why it is called as "Hidden hunger". It is reported that $\mathrm{Zn}$ deficiency will be increased from $49 \%$ to $63 \%$ by (Singh.,2010). Increasing production of peanuts and improve seed quality using $\mathrm{Fe}, \mathrm{Mn}$ and $\mathrm{Zn}$ considered animportant factor especially in poorly nutritive sandy soil (El-Metwally et al. 2018; Abd ElMoneem and Said, 2018 and Hagab et al., 2018).

Nanotechnology has affected all aspects of human life through different productions (Soleimanpouret al.2011). One of the nanotechnology application in agriculture is the use of essential elements in nanoparticulateform (nanoparticles) as nanofertilizers that can be more effective than bulk fertilizers, so that the amount used isvery much lower (Jha et al. 2011). In some new fertilizers, different plant nutrients have been coated with various metal nanoparticles, as an important ingredient in new commercial fertilizers (Dastjerdi et al. 2015; Hagab et al., 2018 and Deb, 2019).

Nanoparticles (NPs) interact with plants causing many morphological and physiological changes, depending on the properties of NPs. Efficacy of NPs is determined by their chemical composition, size, surface covering, reactivity, and most importantly the dose at which they are effective. Researchers from their findings suggested both positive, negative effects on plant growth, development, the impact of NPs on plants depends on the composition, concentration, size, physical and chemical properties of NPs as well as plant species (Hagab et al., 2018).
In many studies, increasing evidence suggests that zinc oxide nanoparticles ( $\mathrm{ZnO}$ NPs) increase plant growth and development. Prasad et al. (2012) studied the effect of nanoscale zinc oxide on the germination, growth and yield of peanut and observed significantly more growth and yield. There are many peanut cultivars grown around the world and several investigations in Egypt have reported that the local and introduced cultivars are genetically and morphologically differed in seed and oil yields (Abd-Alla, 2004; Ali et al., 2004; Ahmed and Rahim, 2007 and Osama and Abdel-Motagally, 2009).

The objective of this study was to elucidate the effect of zinc oxide nanoparticles concentrations as foliar application on peanut seed and oil yields of three peanut cultivars under reclaimed sandy soils conditions in the New Valley.

\section{Materials and Methods}

The present investigation was conducted in the newly reclaimed soils in Farafra of New valley Governorate, Egypt; during 2017 and 2018 seasons to study the impact of foliar spray by zinc oxide nanoparticles on production of peanut cultivars.

\section{Plant materials and experiment layout}

A field experiment was carried out in a randomized complete block design (RCBD) using a strip plot arrangement with three replications. Zinc oxide nanoparticles concentrations ( 0 as control, 200, 400 and 600 $\mathrm{ppm}$ ) were allotted horizontally while, the cultivars (NC9, Gregory and Ismailia1) were a signed vertically. Sub plot included six rows, a 
single row was $3 \mathrm{~m}$ long and spaced $0.50 \mathrm{~cm}$ apart with $0.25 \mathrm{~cm}$ (plot size $10.5 \mathrm{~m}^{2}$ ). Seed were sown on June $14^{\text {th }}$ in both seasons. All other cultural practices recommended for peanut crop under reclaimed soils were done in both seasons. The soil of the experiments was sandy loam, the physical and chemical analysis of the soil were carried out before sowing and presented in Table 1.

\section{Measured traits}

At harvesting, five guarded plants were taken randomly from each subplot for measuring the following data: Number of pods /plant, pods weight (g)/plant, seed weight (g) /plant, 100-seed weight (g), biological yield $(\mathrm{kg} / \mathrm{fed}$.) and seed yield (kg/fed.). Seed oil content was determined by Soxhlet apparatus according to A.O.A.C. (1995). Multiplication of oil percentage by seed yield in $\mathrm{kg} \mathrm{fed}^{-1}$ to obtain oil yield in $\mathrm{kg} \mathrm{fed}^{-1}$.

\section{Statistical analysis}

All collected data were analyzed with analysis of variance (ANOVA) Procedures, using the SAS Statistical Software Package v.9.2 (SAS, 2008). Differences between means were compared by revised least significant difference (R LSD) at 5\% level of significant (Gomez and Gomez, 1984).

\section{Results and Discussion}

The results of the experiment in both seasons are presented and discussed in detailed for each trait separately as follow:

\section{Number of pods / Plant}

There were significant differences among studied peanut cultivars only in the second season (Table 2). Ismailia and NC9 peanut cultivars recorded the highest number of pods/plant (55.26 and 60.16) in 2017 and 2018 seasons, respectively. While the lowest number of pods/plant (51.81 and 54.90) were obtained by Gregory and Ismailia cultivars in the first and second seasons, respectively. This is may be due to the genetic behavior in combination with the environmental conditions which was suitable for Ismailia and NC9 cultivar than Gregory one. The previous results are in accordance with those obtained by Ahmed \& zeidan (2001), Ahmed et al. (2007b) and Atayese (2007).

Furthermore, highly significant differences were observed among tested zinc oxide nanoparticles $(\mathrm{ZnO}$ NPs) concentrations for number of pods/plant in both seasons (Table 2). Since the highest mean values of pods number/plant (71.62 and 83.40 in the first and second seasons, respectively) were obtained when plants sprayed with $600 \mathrm{ppm}$ of $\mathrm{ZnO}$ NPs concentrations, while the lowest values (38.11 and 34.04) were observed under control treatment in both seasons, respectively. This is to be logic since the same trend was observed with regard to number of branches/plant trait (data not shown). These results are in the same trend with that reported by Majumdar et al. (2001).

Also, the exhibited data in Table (2) denote that the interaction between $\mathrm{ZnO}$ NPs concentrations and peanut cultivars were significant $(\mathrm{P} \leq 0.05)$ in the second season only. The highest mean value of pods number/plant in the second season (85.53) was registered from Gregory cultivar which was sprayed by $\mathrm{ZnO}$ NPs at $400 \mathrm{ppm}$. 


\section{Pods weight / Plant:}

The illustrated data in Table (3) show that the tested peanut cultivars failed to reach a significant effect in both seasons. NC9 and Ismailia1 peanut cultivars were surpassed Gregory cultivar in pods weight/plant and registered the heaviest pod weight/plant (87.50 and $79.25 \mathrm{~g}$ ) in 2017 and 2018 seasons, respectively. While the lowest ones (82.16 and $71.91 \mathrm{~g})$ were achieved with Ismailia cultivar in the first season and NC9 cultivar in the second season. This is may be due to the genetic behavior in combination with the environmental conditions which was suitable for NC9 and Ismailia cultivars than Gregory one. The previous results are in accordance with those obtained by Ahmed \& zeidan (2001), Ali et al. (2004), Ahmed et al. (2007b).

In addition, the analysis of variance reveled highly significant differences among zinc oxide nanoparticles concentrations for pods weight/plant in both seasons (Table 3). Furthermore, the heaviest values of pod weight / plant (117.22 and $104.88 \mathrm{~g}$ in the two respective seasons) were obtained from $600 \mathrm{ppm}$ of $\mathrm{ZnO}$ NPs concentration, while the thinnest ones $(55.62$ and $51.00 \mathrm{~g})$ were found at the control in the first and second seasons, respectively. This is to be logic since the same trend was observed with regard to number of pods / plant trait as mentioned before (Tables 2). These findings are in a good line with those obtained by Majumdar et al. (2001).

Also, it is clear from recorded data in Table (3) that the interaction between $\mathrm{ZnO}$ NPs concentrations and peanut cultivars was a highly signifi- cant regarding pods weight/plant in both seasons. The heaviest pod weight/ plant (130.66 g) was noted from NC9 cultivar which was sprayed by $\mathrm{ZnO}$ NPs at $600 \mathrm{ppm}$ in the first season, while in the second season the heaviest pod weigh/ plant (116.66 g) was recorded from Ismailia cultivar which was sprayed by $\mathrm{ZnO}$ NPs at $600 \mathrm{ppm}$, as well as the NC9 cultivar under the control (without $\mathrm{ZnO}$ NPs) gave the 200ppm lightest ones (44.33 and $49.00 \mathrm{~g}$ in the two growing seasons).

\section{Weight of 100 seeds (g):}

Non-significant differences were observed among peanut cultivars in both seasons (Table 4) for 100 -seed weight. NC9 and Gregory cultivars were surpassed Ismailia cultivar in this respect and registered the maximum values of 82.50 and 94.16 $\mathrm{g}$ for the weight of 100 seeds in the first and second seasons, respectively. While the minimum values of weight of 100-seed were 78.75 and $86.25 \mathrm{~g}$ which achieved with Ismailia cultivar in the two respective seasons, respectively These results are in agreement with those reported by Ahmed et al. (2007b), Annadurai et al. (2009), Mohamed (2009).

Here too, weight of 100 seeds trait was affected highly significantly by the ( $\mathrm{ZnO}$ NPs) concentrations in both seasons (Table 4). The maximum values in this trait were 88.88 and $100.55 \mathrm{~g}$ in the first and second seasons, respectively were obtained from peanut plants which were sprayed by $\mathrm{ZnO}$ NPs concentration at $600 \mathrm{ppm}$. While the minimum values were 71.66 and $81.66 \mathrm{~g}$ in the first and second seasons were found at $200 \mathrm{ppm}$. This may be due to the zinc 
oxide nanoparticles increase the zinc absorption via peanut plants and consequently increased photosynthesis process which led to an increment in metabolic translocation from sources to seeds. These findings are in a good line with those obtained by Babaeian et al. (2011), Al-Doori (2013) and Laware and Shilpa (2014).

Moreover, the interaction between ZnO NPs concentrations and peanut cultivars failed to reach a significant effect at $5 \%$ level of probability in the first and second seasons, respectively (Table 4 ). These findings are in a good line with those obtained by Al-Doori (2013).

\section{Seed weight/plant (g):}

Data in Table (5) revel that zinc oxide ( $\mathrm{ZnO} \mathrm{NPs}$ ) concentrations had a highly significant $(\mathrm{P} \leq 0.01)$ effect on seed weight/plant $(\mathrm{g})$ in the two growing seasons. Thus, the heaviest seed weight/plant were52.33 and $47.36 \mathrm{~g}$ in the first and second seasons, respectively were obtained from $600 \mathrm{ppm}$ of $\mathrm{ZnO}$ NPs concentration. While the lightest seed weight/plant were 41.67 and $34.33 \mathrm{~g}$ which were found at the control (without $\mathrm{ZnO}$ NPs) in the first and second seasons, respectively. This is due to the same trend was observed with regard to number of pod and weight of 100 seeds traits as mentioned before. These results are in agreement with those reported by Laware and Shilpa (2014).

Moreover, the exhibited data in Table (5) focus that the tested peanut cultivars had a significant influence on seed weight/plant trait in the first season only while, to failed to reach a significant effect in the second season. In addition, NC9 and Gregory peanut cultivars were superior Ismailia in this trait and gave the highest mean values of seeds weight/plant (49.00 and 40.21g), while the lightest ones (45.67and 38. 90g) were achieved with Ismailia and $\mathrm{Nc} 9$ cultivar in the two respective seasons, respectively. This is may be due to the increase in number of pod and weight of 100 seeds. These results are in accordance with those reported by Ali et al. (2004), Mohamed (2009).

Also, the obtained data in Table (5) reveal that the interaction between $\mathrm{ZnO}$ NPs concentrations and peanut cultivars had a highest significant influence on seed weight / plant trait in the second season only but, it failed to reach a significant effect in the first season. The heaviest seed weight / plant (55.67 and $48.17 \mathrm{~g}$ in the two respective seasons) were obtained from NC9 and Gregory cultivars which was sprayed by ZnO NPs at $600 \mathrm{ppm}$, while the Gregory and Ismailia cultivars under the control (without $\mathrm{ZnO}$ NPs) gave the lightest ones (39.67 and 33.67) in the two growing seasons.

\section{Biological yield/ fed.}

Biological yield $(\mathrm{kg} / \mathrm{fed})$ trait reacted highly significantly $(\mathrm{P} \leq 0.01)$ to the tested concentrations $(\mathrm{ZnO}$ NPs) in the second growing season only (Table 6). Thus, the maximum values of biological yield trait (1.62 and 1.70 in the first and second seasons, respectively) were obtained from $600 \mathrm{ppm}$ of $\mathrm{ZnO}$ NPs concentration, while the minimum one (1.15 and 1.11) was found at the control in the first and second seasons, respectively. The previous results are in accordance with those obtained by Babaeian et al. (2011) and Ghasemi et 
al. (2017). Also, the recorded data in Table (6) denote that the tested Peanut cultivars had a significant influence on biological yield trait in second season only Moreover, NC9 and Gregory cultivars were superior Ismailia one in this trait and gave the maximum values of biological yield trait (1.42 and $1.44 \mathrm{~kg}$ in the two respective seasons), while the minimum ones (1.31and $1.30 \mathrm{~kg}$ ) were achieved with Ismailia and Gregory cultivars in the two respective seasons. These results are in accordance with those reported by Abd-Alla (2004) and Mohamed (2009).

Concerning the interaction effect on biological yield, the exhibited data in (Table 6) reveal that the interaction between $\mathrm{ZnO}$ NPs concentrations and peanut cultivars had a highly significant effect in the second season. The maximum values of biological yield were 1.70 and $1.78 \mathrm{~kg}$ in the first and second seasons, respectively, which were obtained from Gregory and NC9 cultivars which was sprayed by ZnO NPs at 600 ppm, as well as the Ismailia and Gregory cultivars under the control (without $\mathrm{ZnO}$ NPs) gave the minimum ones $(1.11$ and $1.02 \mathrm{~kg}$ ) in the two growing seasons.

\section{Seed yield (kg/ fed.)}

Seed yield $(\mathrm{kg} / \mathrm{fed})$ trait reacted highly significantly $(\mathrm{P} \leq 0.01)$ to the tested $\mathrm{ZnO}$ NPs concentrations ( $\mathrm{ZnO}$ NPs) in the two growing seasons (Table 7). Since the highest mean values of seed yield trait were 588.09 and $659.64 \mathrm{~kg} / \mathrm{fed}$. in the first and second seasons, respectively which were obtained from 400ppm and 600 ppm of ZnO NPs concentration. This is to be expected since the same trend was observed regarding seed weight (Table 5). While the minimum ones were 533.33 and $497.87 \mathrm{~kg} /$ fed. were found at the control and $200 \mathrm{ppm}$ in the first and second seasons. The previous results are in accordance with those obtained by Gitte et al. (2005) and Patel (2016).

Also, the recorded data in Table 7 denote that the tested peanut cultivars had a significant influence on seed yield trait in the first season only while, peanut cultivars failed to reach a significant effect in the second season. Furthermore, NC9 cultivar was superior Gregory and Ismailia in this respect and gave the highest mean values of seed yield (574.40 and $587.13 \mathrm{~kg} / \mathrm{fed}$. in the two respective seasons). This is to be expected since the same trend was observed with regard to seed weight/plant. while the minimum ones (555.73and 564.60 $\mathrm{kg} /$ fed.) were achieved with Ismailia and Gregory cultivars in the two respective seasons. These results are in agreement with those reported by Osama and Abdel-Motagally (2009).

Concerning the interaction effect on seed yield trait, the exhibited data in Table 10 reveal that the interaction between $\mathrm{ZnO}$ NPs concentrations and peanut cultivars failed to reach a significant effect at 5\% level of probability in the two successive seasons. The highest mean values of seed yield trait (611.73 and 590.13 $\mathrm{kg} / \mathrm{fed}$. in the first and second seasons, respectively) were obtained from NC9 cultivar which was sprayed by $\mathrm{ZnO}$ NPs at $600 \mathrm{ppm}$. as well as the Gregory cultivar under the control (without $\mathrm{ZnO}$ NPs) gave the minimum ones were 522.13 and 488.53 $\mathrm{kg} /$ fed. In the first and second sea- 
sons, respectively. Similar trend was observed by Al-Doori (2013).

\section{Oil yield (kg/ fed.):}

It is clear from the data in Table 8 that the zinc oxide nanoparticles concentrations had a highly significant $(\mathrm{P} \leq 0.01)$ effect on oil yield. Where, the heaviest mean of values of oil yield (295.23and $321.73 \mathrm{~kg} / \mathrm{fed}$. in the first and second seasons, respectively) were obtained from 400 and $600 \mathrm{ppm} \mathrm{ZnO}$ NPs concentration. This is to be logic, since the same trend was observed with regard to seed yield traits as mentioned before. while the minimum one (259.55and $230.51 \mathrm{~kg} / \mathrm{fed}$.) were found at control (without ZnO NPs) in the first and second seasons. These results are in agreement with those reported by Sankaran et al. (2001) and Al-Doori (2013).

Data in the same table exhibited that the studied peanut cultivars failed to reach a significant effect at $5 \%$ level of probability in the two growing seasons. Hence, Gregory and Ismailia cultivars in this respect gave the highest mean values of oil yield (278.14 and $279.63 \mathrm{~kg} / \mathrm{fed}$ in the two respective seasons). This is to be expected since the same trend was observed with regard to seed yield trait as mentioned before (Table 7). While the minimum ones (274.63 and $273.90 \mathrm{~kg} / \mathrm{fed}$.) were achieved with NC9 cultivar in the two respective seasons. These results are in agreement with those reported by Howlader et al. (2009).

Also, the obtained data in Table 14 reveal that the interaction between $\mathrm{ZnO}$ NPs concentrations and sunflower cultivars had a highly significant effect on oil yield. The highest mean values of oil yield (723.61 and $701.37 \mathrm{~kg} / \mathrm{fed}$. in the two respective seasons) were obtained from Giza 102 cultivar which was sprayed by $\mathrm{ZnO}$ NPs at $200 \mathrm{ppm}$ than Sakha 53 one. as well as the Gregory and NC9 cultivars under the control (without $\mathrm{ZnO} \mathrm{NPs}$ ) and $200 \mathrm{ppm}$ gave the minimum ones (46.57and $45.36 \%$ ) in the two growing seasons. These results are in agreement with that reported by Al-Doori (2013).

\section{Conclusions}

From the previous results, it could be concluded that the analysis of variance revealed highly significant variation among peanut cultivars and zinc nanoparticles concentrations for the most studied traits in the two tested seasons under Farfra conditions. Furthermore, the interaction between peanut cultivars and the concentrations of zinc nanoparticles was significant in most cases in both seasons. This result indicates the variability of the genetic response of the peanut cultivars to the spray by zinc nanoparticles on the growth and productivity of peanut cultivars compared to the non-sprayed plants (control). Since all peanut cultivars showed remarkable positive responses to the spray of zinc nanoparticles. In most cases, an enhancement was observed in most studied traits by increasing the concentration from $200 \mathrm{ppm}$ to $600 \mathrm{ppm}$. Also, NC9 cultivar gave the highest seed yield $(\mathrm{kg} / \mathrm{fed})$ in both seasons, while there were non-significant differences among peanut cultivars for oil yield (kg/fed) but as an average over both seasons, NC9 gave the highest oil yield $(\mathrm{kg} / \mathrm{fed})$. Therefore, it could be recommended that $\mathrm{NC} 9$ cultivar with 
spraying by zinc nanoparticles is a good choice for planting and production under newly reclaimed soils in the Farafra region with other important recommended agronomical practices for such region.

\section{References}

A.O.A.C. (1995). Association of Official Analytical Chemists'. Official methods of analysis, $16^{\text {th }}$ Ed. AOAC International, Washington, D.C., USA.

Abd_Alla, Maha M. (2004). Effect of certain agricultural practices on productivity of peanut. Influence of sowing dates and potassium application on yield and yield attributes of some peanut cultivars. Zagazig J. of Agric. Res.31.3: 843866.

Abde-El-Monem, A., and Said, M.T. (2018). Response of Some Peanut Genotypes to Phosphorus Fertilization Levels Under New Valley Conditions. Assiut Journal of Agricultural Sciences, 49(1), 1-9.

Ahmed, M. K.; and M. S. Zeidan (2001) 'Yield and quality of two peanut cultivars as affected by methods of potassium application'. Egy. J. of Applied Sci. 16.7: 114-126.

Ahmed, N. and M. Rahim (2007). Evaluation of promising groundnut (Arachis hypogaea L.) Varieties for yield and other characters'. J. Agric. Res., 45 (3): 185-189.

Ahmed, N.; M. Rahim and U. Khan (2007a). Evaluation of various dates for groundnut varieties under agro-ecological conditions of malakand division'. Gomal Univ., J. of Res., 23 (2): 1-4.

Ahmed, N.; M. Rahim and U. Khan (2007b). Evaluation of different Varieties, seed rates and row spacing of groundnut planted under Agro-ecological conditions of Malakand division'. J. of Agro. 6 (2):385-387.
Al-Doori, S.A.M. (2013). Effect of Different Levels and Timing of Zinc Foliar application on Growth, Yield and Quality of Sunflower Genotypes (Helian- thus). Zinc coordination sphere in biochemical zinc sites. In Zinc Biol., Phys- iol. and Homeo., (pp. 85-127). Springer.

Ali, A.A.G.; 0.A. Zeiton, H.G.M. Geweifel and M.A. Taha (2004). Some factors affecting productivity of peanut (Arachis hypogaea $L$.) in newly cultivated sandy soil. Zagazig J. Agric. Res., 31 (6): 2565-2595.

Annadurai, K.; P. Naveen; A. Sangu and P. Masilamani (2009). Agronomic management technologies for peanut production: a review. Agric. Reviews 30.4: 235-261.

Anonymous, J (2015). United States department of agriculture, national agri-cultural statistics service. Crop Prod. 2014 Summ. ISSN: 1057-7823.

Arioglu, H.H (2014). The Oil Seed Crops Growing and Breeding. The Publication of University of Cukurova, Faculty of Agric. AdanaTurkey. No: A-70, pp. 204.

Atayese, M.O. (2007). Field response of groundnut (Arachis hypogea L.) cultivars to mycorrhizal inoculation and phosphorus fertilizer in Abeokuta, South West Nigeria. American-Eurasian J. of Agric. Environ.Sci. 2.1 (2007): 16-23.

Babaeian, M.; I. Piri; A. Tavassoli; Y. Esmaeilian and H. Gholami (2011). Effect of water stress and micronutrients ( $\mathrm{Fe}, \mathrm{Zn}$ and $\mathrm{MN}$ ) on chloro phyll fluorescence, leaf chlorophyll content and sunflower nutrient uptake in Sistan region. Afr. J. Agric. Res., 6(15): 35263531.

Dastjerdi, E. B., Sahid, I. B., \& Jusoh, K. B. (2015) 'Effects of zinc oxide 
nano-particles on groundnut (Arachis hypogaea) seedlings. In AIP Conference Proceedings (Vol. 1678, No. 1, p. 020012). AIP Publishing LLC.

Deb, N. (2019). Plant nutrient coated nanoparticles and methods for their preparation and use. U.S. Patent 10,196,319 issued February 5, 2019.

El-Metwally, I.M., Doaa, M.R. and AboBasha, A. E.A.M. (2018). Response of peanut plants to different foliar applications of nano-iron, manganese and zinc under sandy soil conditions. Middle East J. Appl. Sci, 8(2), 474-482.

FAO (2018). www.Fao.org (C.F. Computer Research).

Ghasemi, M.; G.N. Mohammad; H. Madani; H.R. Mobasser and M.Nouri (2017). Effect of foliar application of zinc Nano oxide on Agronomic trait of two varieties of rice (Oryza sativa L.). Crop Res. 52 (6): 195 201.

Gitte, A.N.; S.R. Patil and M.A. Tike (2005). Influence of zinc and boron on bio- chemical and yield characteristics of sunflower. J. of plant Physiology. 10(4): 431-438.

Gomez, K.A. and A.A. Gomez (1984). Statistical Procedures for Agric. Res., $2^{\text {nd }}$ Edn. John Wily and Sons, New York, pp: 68.

Hagab, R.H., Kotp, Y.H., and Eissa, D. (2018). Using nanotechnology for enhancing phosphorus fertilizer use efficiency of peanut bean grown in sandy soils. Journal of Advanced Pharmacy Education \& Research| Jul-Sep, 8(3).

Howlader, S. H.; H.M.K. Bashar.; M.S. Islam; M.H. Mamun and S.M.H. Jahan (2009). Effect of plant spacing's on the yield and yield attributes of groundnut. Inter. J. of Sustain. Crop Prod. 4.1: 41-44.
Jha, Z., N. Behar, S.N. Sharma, G. Chandel, D. Sharma \& M. Pandey (2011). Nanotechnology: prospects of agricultural advancement. Nano Vision 1(2): 88-100.

Laware, S. L. and R. Shilpa (2014). Influence of $\mathrm{ZnO}$ nanoparticles on growth, growth, flowering and seed productivity in onion. Int. J. Current Microbi. and Appl. Sci., 3: 874-881.

Majumdar, B.; M. S. Venkatesh; B. Lal; K. Kumar and C. S. Singh (2001). Effect of phosphorous and zinc nutrition on groundnut in acid hapludalf of Meghalaya. Ann. Agric., Res. New Series, (22): 354359.

Mohamed, M.A.H. (2009). Response of some peanut varieties to Potassium and foliar application with boron at the New Valley'. Ph.D. Thesis, Fac. of Agric., Assiut Univ., Egypt.

Osman, E.A. and Abdel-Motagally, F.M.F., (2009). Improving the productivity of some peanut genotypes grown in newly reclaimed soil at East of El-Ewinate in relation to different rates of fertilization. Egypt. J. of Appl. Sci, 24(8B), pp.540-552.

Patel, K (2016). Effect of ZnO nanoparticles on germination, growth and yield of groundnut (Arachis hypogaea L.). Ph. D. Thesis, Dep of Soil Sci and Agri. Chem. Anand Agricultural University. India.

Prasad, T. N. V. K. V., Sudhakar, P., Sreenivasulu, Y., Latha, P., Munaswamy, V., Reddy, K. R., ... \& Pradeep, T. (2012). Effect of nanoscale zinc oxide particles on the germination, growth and yield of peanut. Journal of plant nutrition, 35(6), 905-927.

Sankaran, M. S.; S. Mani. and S. Savtthri (2001). Effect of teprosyn and zinc on yield and quality parameters of 
sunflower (Helianthus annuus L.), Madras J. of Agric., 88 (10-12). 717- 718.

SAS institute (2008). The SAS System for Windows release 9.2. Cary NC: SAS in- statute.

Singh, M.V.(2010). Micronutrient nutritional problems in soil of indian and improvement for human and animal health. Indian Jounal of Fertlizer. 5(4): 11-56.
Soleimanpour, M.R., S.J.F. Hosseini, S.M. Mirdamadi \& A. Sarafrazi (2011). 'Challenges in commercialization of nanotechnology in agriculture sector of Iran'. Annals of Biological Research 2 (4).

Zuo, Y. and F.S. Zhang (2011). Soil and crop management strategies to prevent iron deficiency in crops. Plant Soil, 339:83-95. 
تأثير الرش الورقي بأكسيد الزنك النانوميتري على إنتاج الفول السوداني تحت ظروف الوادي الجديد

السعدي عبدالحميا علي، محمد ثروت سعيد، محمد عبدالعزيزعبدالحليم سيد ومحمد رجب سنوسي

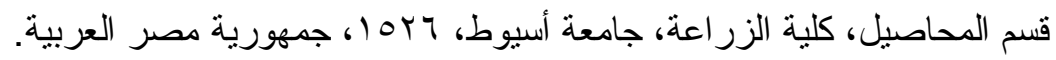

تعد زيادة إنتاج البذور و الزيوت من المحاصيل الزيتية في التربة المستصلحة هدقا مهمًا

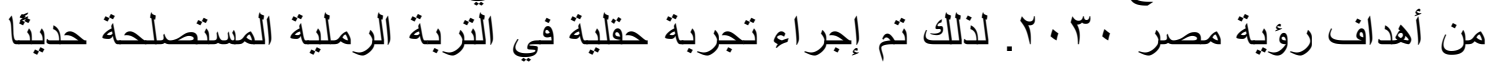

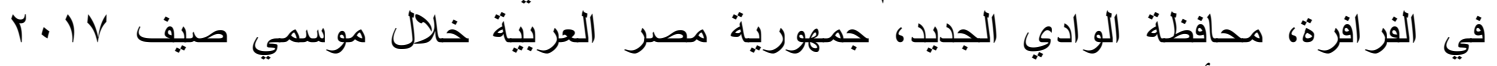

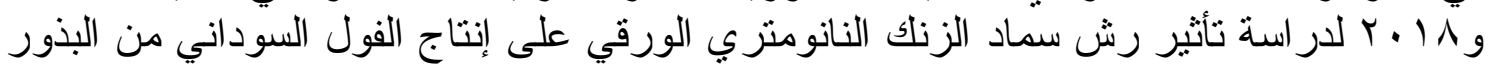

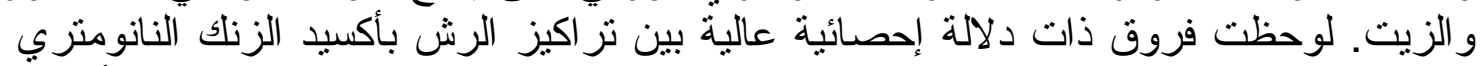

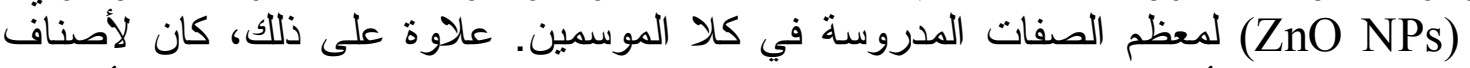

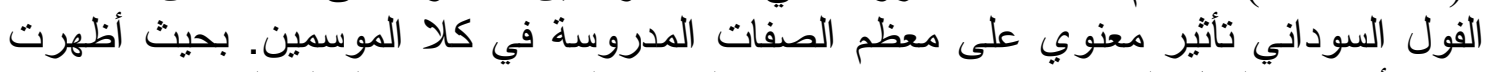

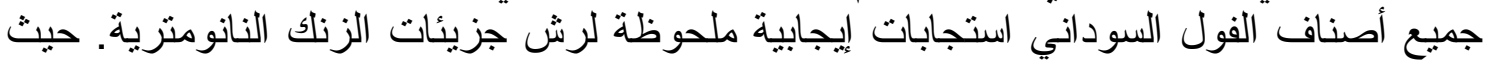

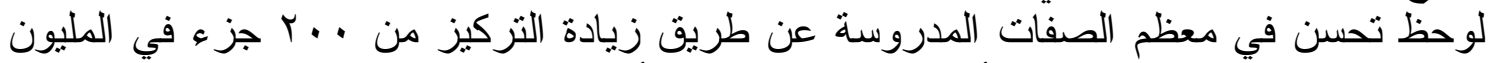

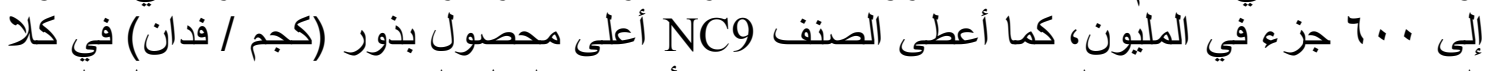

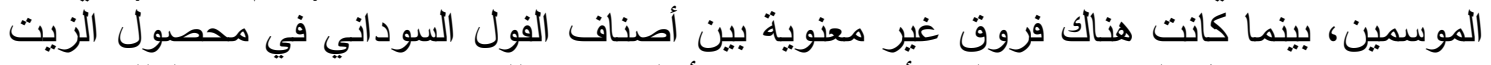

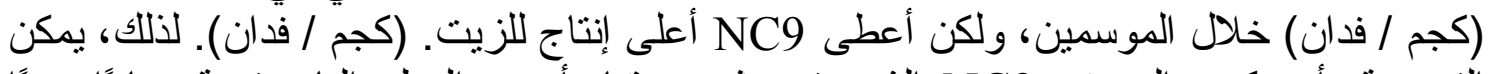

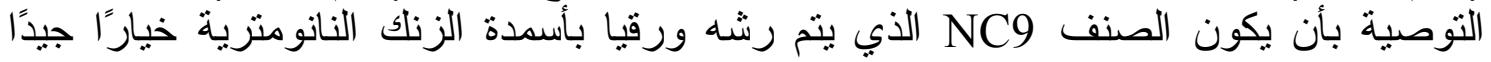

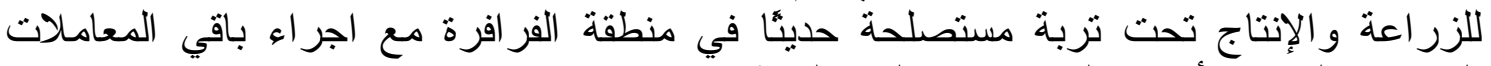
الزر اعية الهامة الأخرى الموصي بها لهذه الهنئة المنطقة. 
Table 1. Soil physical and chemicals analysis of the experimental site.

\begin{tabular}{|c|c|}
\hline Characteristic & Values \\
\hline \multicolumn{2}{|l|}{ Particle size distribution } \\
\hline Sand, $\%$ & 75.10 \\
\hline Silt, \% & 10.90 \\
\hline Clay, \% & 14.00 \\
\hline Soil texture & Sandy loam \\
\hline Field capacity, \% & 13.20 \\
\hline Wilting point $\%$ & 6.10 \\
\hline Saturation water, $\%$ & 21.00 \\
\hline Bulk density, $\mathrm{gm} / \mathrm{cm}^{3}$ & 1.70 \\
\hline $\mathrm{Ph}$ & 7.70 \\
\hline Total soluble salt, EC1:1 $\mathrm{dSm}^{-1}$ & 0.31 \\
\hline $\mathrm{CaCO}_{3}$ & 12.10 \\
\hline Soluble Cations in soil $(1: 1)$ & $\mathrm{meq} / \mathrm{kg}$ \\
\hline $\mathrm{Ca}^{2+}$ & 1.50 \\
\hline $\mathrm{Mg}^{2+}$ & 0.50 \\
\hline $\mathrm{Na}^{+}$ & 1.10 \\
\hline $\mathrm{K}^{+}$ & 0.30 \\
\hline \multicolumn{2}{|l|}{ Soluble Anions } \\
\hline $\mathrm{Cl}^{-}$ & 2.30 \\
\hline $\mathrm{HCO}_{3}{ }^{-}+\mathrm{CO}_{3}{ }^{2-}$ & 0.50 \\
\hline $\mathrm{SO}_{4}{ }^{2}$ & 0.80 \\
\hline Total nitrogen $\%$ & 0.01 \\
\hline A available phosphorus ppm & 9.10 \\
\hline \multicolumn{2}{|l|}{ Analysis of the zinc in soil and water } \\
\hline Soil & $0.84 *(\mathrm{mg} / \mathrm{kg})$ \\
\hline Water & 0.00 \\
\hline
\end{tabular}

*Zn was determined using the Inductively Coupled Plasma Emission Spectrometer) (ICAP6200) 
Table 2. Means of pods number/plant as affected by zinc oxide nanoparticles concentrations, peanut cultivars, and their interaction in 2017 and 2018 seasons.

\begin{tabular}{|c|c|c|c|c|c|c|c|c|}
\hline \multirow{3}{*}{$\begin{array}{c}\text { Zinc oxide nanopar- } \\
\text { ticles } \\
\text { (ppm) }\end{array}$} & \multicolumn{4}{|c|}{2017} & \multicolumn{4}{|c|}{2018} \\
\hline & \multicolumn{3}{|c|}{ Cultivars } & \multirow[b]{2}{*}{ Mean } & \multicolumn{3}{|c|}{ Cultivars } & \multirow[b]{2}{*}{ Mean } \\
\hline & $\underset{z}{\partial}$ & 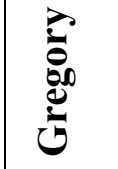 & 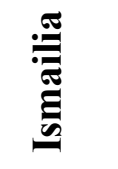 & & 己े & : & : & \\
\hline Control & 35.13 & 40.86 & 38.33 & 38.11 & 35.86 & 33.93 & 32.33 & 34.04 \\
\hline 200 & 38.40 & 37.80 & 40.20 & 38.80 & 36.93 & 35.60 & 34.60 & 35.71 \\
\hline 400 & 65.86 & 60.66 & 69.26 & 65.26 & 82.86 & 85.53 & 72.80 & 80.40 \\
\hline 600 & 73.66 & 67.93 & 73.26 & 71.62 & 85.00 & 85.33 & 79.86 & 83.40 \\
\hline Mean & 53.26 & 51.81 & 55.26 & ----- & 60.16 & 60.10 & 54.90 & ---- \\
\hline F test and R. LSD & \multicolumn{2}{|c|}{ F test } & \multicolumn{2}{|c|}{ R. LSD 0.05} & \multicolumn{2}{|c|}{ F test } & \multicolumn{2}{|c|}{ R. LSD 0.05} \\
\hline $\mathrm{ZnO} \mathrm{NPs}$ & \multicolumn{2}{|c|}{$* *$} & \multicolumn{2}{|c|}{10.37} & \multicolumn{2}{|c|}{$* *$} & \multicolumn{2}{|c|}{2.68} \\
\hline Cultivars & \multicolumn{2}{|c|}{ Ns } & \multicolumn{2}{|r|}{-} & \multicolumn{2}{|r|}{ * } & \multicolumn{2}{|c|}{3.56} \\
\hline Interaction & \multicolumn{2}{|c|}{ Ns } & \multicolumn{2}{|c|}{--} & \multicolumn{2}{|r|}{ 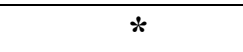 } & \multicolumn{2}{|c|}{5.05} \\
\hline
\end{tabular}

Where Ns, * and ${ }^{* *}$ mean non-significant, significant at 5 and $1 \%$ level of probability, respectively.

Table 3.Means of pods weight/plant as affected by zinc oxide nanoparticles concentrations, peanut cultivars and their interaction in 2017 and 2018 seasons.

\begin{tabular}{|c|c|c|c|c|c|c|c|c|}
\hline Season & \multicolumn{4}{|c|}{2017} & \multicolumn{4}{|c|}{2018} \\
\hline \multirow[b]{2}{*}{$\begin{array}{c}\text { Zinc oxide } \\
\text { nanoparticles } \\
\text { (ppm) }\end{array}$} & \multicolumn{3}{|c|}{ Cultivars } & \multirow[b]{2}{*}{ Mean } & \multicolumn{3}{|c|}{ Cultivars } & \multirow[b]{2}{*}{ Mean } \\
\hline & 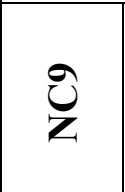 & فํ. & : & & $\underset{z}{Z}$ & 总 & 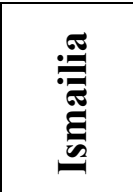 & \\
\hline Control & 44.33 & 69.53 & 53.00 & 55.62 & 50.00 & 50.00 & 53.00 & 51.00 \\
\hline 200 & 53.33 & 65.53 & 62.33 & 60.40 & 49.00 & 50.33 & 50.66 & 51.00 \\
\hline 400 & 121.66 & 94.33 & 108.33 & 108.11 & 88.66 & 97.66 & 96.66 & 94.33 \\
\hline 600 & 130.66 & 116.00 & 105.00 & 117.22 & 100.00 & 98.00 & 116.66 & 104.88 \\
\hline Mean & 87.50 & 86.35 & 82.16 & ----- & 71.91 & 74.00 & 79.25 & ---- \\
\hline F test and & \multicolumn{2}{|c|}{ F test } & \multicolumn{2}{|c|}{ R. LSD 0.05} & \multicolumn{2}{|c|}{ F test } & \multicolumn{2}{|c|}{ R. LSD 0.05} \\
\hline ZnO NPs & \multicolumn{2}{|r|}{$* *$} & \multicolumn{2}{|c|}{10.83} & \multicolumn{2}{|c|}{$* *$} & \multicolumn{2}{|c|}{5.14} \\
\hline Cultivars & \multicolumn{2}{|r|}{ Ns } & \multicolumn{2}{|r|}{---} & \multicolumn{2}{|c|}{ Ns } & \multicolumn{2}{|r|}{--- } \\
\hline Interaction & \multicolumn{2}{|r|}{$* *$} & \multicolumn{2}{|r|}{7.26} & \multicolumn{2}{|c|}{$* *$} & \multicolumn{2}{|r|}{6.46} \\
\hline
\end{tabular}

Where Ns, $*$ and $* *$ mean non-significant, significant at 5 and $1 \%$ level of probability, respectively. 
Table 4. Means of 100-seed weight/plant (g) as affected by zinc oxide nanoparticles concentrations, peanut cultivars and their interaction in 2017 and 2018 seasons.

\begin{tabular}{|c|c|c|c|c|c|c|c|c|}
\hline Season & \multicolumn{4}{|c|}{2017} & \multicolumn{4}{|c|}{2018} \\
\hline \multirow{2}{*}{$\begin{array}{c}\text { Zinc oxide nanopar- } \\
\text { ticles } \\
\text { (ppm) }\end{array}$} & \multicolumn{3}{|c|}{ Cultivars } & \multirow[b]{2}{*}{ Mean } & \multicolumn{3}{|c|}{ Cultivars } & \multirow[b]{2}{*}{ Mean } \\
\hline & $\begin{array}{l}\text { 己 } \\
\mathbf{Z}\end{array}$ & 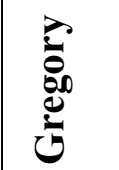 & : & & $\begin{array}{l}\text { Zे } \\
\text { z }\end{array}$ & לై & 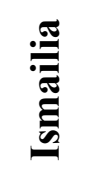 & \\
\hline Control & 71.66 & 78.33 & 73.33 & 74.44 & 86.66 & 81.66 & 78.33 & 82.22 \\
\hline 200 & 73.33 & 75.00 & 71.66 & 73.33 & 83.33 & 80.00 & 81.66 & 81.66 \\
\hline 400 & 85.00 & 90.00 & 83.33 & 86.11 & 103.33 & 98.33 & 90.00 & 97.22 \\
\hline 600 & 93.33 & 86.66 & 86.66 & 88.88 & 103.33 & 103.33 & 95.00 & 100.55 \\
\hline Mean & 80.83 & 82.50 & 78.75 & $\begin{array}{ll}---- \\
\end{array}$ & 94.16 & 90.83 & 86.25 & ---- \\
\hline F test and R. LSD & \multicolumn{2}{|c|}{ F test } & \multicolumn{2}{|c|}{ R. LSD 0.05} & \multicolumn{2}{|c|}{ F test } & \multicolumn{2}{|c|}{ R. LSD 0.05} \\
\hline ZnO NPs & \multicolumn{2}{|c|}{$* *$} & \multicolumn{2}{|c|}{3.95} & \multicolumn{2}{|r|}{$* *$} & \multicolumn{2}{|c|}{4.67} \\
\hline Cultivars & \multicolumn{2}{|c|}{ Ns } & \multicolumn{2}{|r|}{--- } & \multicolumn{2}{|r|}{ Ns } & \multicolumn{2}{|c|}{---} \\
\hline Interaction & \multicolumn{2}{|c|}{ Ns } & \multicolumn{2}{|r|}{-- } & \multicolumn{2}{|r|}{ Ns } & \multicolumn{2}{|r|}{--- } \\
\hline
\end{tabular}

Where Ns, ${ }^{*}$ and $* *$ mean non-significant, significant at 5 and $1 \%$ level of probability, respectively.

Table 5. Means of seed weight/plant (g) as affected by zinc oxide nanoparticles concentrations, peanut cultivars, and their interaction in 2017 and 2018 seasons.

\begin{tabular}{|c|c|c|c|c|c|c|c|c|}
\hline \multirow{3}{*}{$\begin{array}{c}\text { Zinc oxide nanoparti- } \\
\text { cles } \\
\text { (ppm) }\end{array}$} & \multicolumn{4}{|c|}{2017} & \multicolumn{4}{|c|}{2018} \\
\hline & \multicolumn{3}{|c|}{ Cultivars } & \multirow[b]{2}{*}{ Mean } & \multicolumn{3}{|c|}{ Cultivars } & \multirow[b]{2}{*}{ Mean } \\
\hline & $\stackrel{\partial}{Z}$ & 递 & 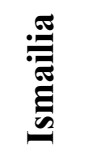 & & $\stackrel{\partial}{Z}$ & 总 & 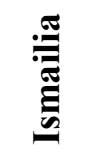 & \\
\hline Control & 43.67 & 39.67 & 41.67 & 41.67 & 35.67 & 33.67 & 33.67 & 34.33 \\
\hline 200 & 43.33 & 42.67 & 43.33 & 43.11 & 36.93 & 36.33 & 34.33 & 35.87 \\
\hline 400 & 53.33 & 51.6 & 49.33 & 51.42 & 35.33 & 42.67 & 45.33 & 41.11 \\
\hline 600 & 55.67 & 53.00 & 48.33 & 52.33 & 47.67 & 48.17 & 46.25 & 47.36 \\
\hline Mean & 49.00 & 46.75 & 45.67 & ---- & 38.90 & 40.21 & 39.89 & ----- \\
\hline F test and R. LSD 0.05 & \multicolumn{2}{|c|}{ F test } & \multicolumn{2}{|c|}{ R. LSD 0.05} & \multicolumn{2}{|c|}{ F test } & \multicolumn{2}{|c|}{ R. LSD 0.05} \\
\hline ZnO NPs & \multicolumn{2}{|c|}{$* *$} & \multicolumn{2}{|c|}{5.52} & \multicolumn{2}{|c|}{$* *$} & \multicolumn{2}{|c|}{4.76} \\
\hline Cultivars & \multicolumn{2}{|c|}{ * } & \multicolumn{2}{|c|}{2.14} & \multicolumn{2}{|c|}{ Ns } & \multicolumn{2}{|c|}{---} \\
\hline Interaction & \multicolumn{2}{|c|}{ Ns } & \multicolumn{2}{|r|}{---} & \multicolumn{2}{|c|}{$* *$} & \multicolumn{2}{|c|}{2.56} \\
\hline
\end{tabular}

Where Ns, $*$ and $* *$ mean non-significant, significant at 5 and $1 \%$ level of probability, respectively. 
Table 6. Means of pods biological yield/fed. (ton/fed.) as affected by zinc oxide nanoparticles concentrations, peanut cultivars, and their interaction in 2017 and 2018 seasons.

\begin{tabular}{|c|c|c|c|c|c|c|c|c|}
\hline \multirow{3}{*}{$\begin{array}{c}\text { Zinc oxide nanopar- } \\
\text { ticles } \\
(\mathrm{ppm})\end{array}$} & \multicolumn{4}{|c|}{2017} & \multicolumn{4}{|c|}{2018} \\
\hline & \multicolumn{3}{|c|}{ Cultivars } & \multirow[b]{2}{*}{ Mean } & \multicolumn{3}{|c|}{ Cultivars } & \multirow[b]{2}{*}{ Mean } \\
\hline & $\underset{z}{z}$ & 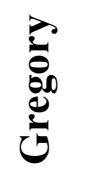 & : & & $\stackrel{\theta}{z}$ & לั. & 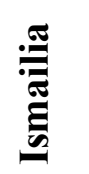 & \\
\hline Control & 1.15 & 1.18 & 1.11 & 1.15 & 1.27 & 1.02 & 1.05 & 1.11 \\
\hline 200 & 1.29 & 1.21 & 1.18 & 1.22 & 1.29 & 1.17 & 1.16 & 1.20 \\
\hline 400 & 1.62 & 1.58 & 1.37 & 1.52 & 1.41 & 1.37 & 1.45 & 1.41 \\
\hline 600 & 1.59 & 1.70 & 1.58 & 1.62 & 1.78 & 1.66 & 1.66 & 1.70 \\
\hline Mean & 1.42 & 1.42 & 1.31 & ---- & 1.44 & 1.30 & 1.33 & -ב-- \\
\hline F test and R. LSD & \multicolumn{2}{|c|}{ F test } & \multicolumn{2}{|c|}{ R. LSD 0.05} & \multicolumn{2}{|c|}{ F test } & \multicolumn{2}{|c|}{ R. LSD 0.05} \\
\hline ZnO NPs & \multicolumn{2}{|c|}{ Ns } & \multicolumn{2}{|c|}{--} & \multicolumn{2}{|c|}{$* *$} & \multicolumn{2}{|c|}{0.13} \\
\hline \begin{tabular}{|l|} 
Cultivars \\
\end{tabular} & \multicolumn{2}{|c|}{ Ns } & \multicolumn{2}{|c|}{-} & \multicolumn{2}{|r|}{ * } & \multicolumn{2}{|c|}{0.07} \\
\hline Interaction & \multicolumn{2}{|c|}{ Ns } & \multicolumn{2}{|c|}{--} & \multicolumn{2}{|c|}{$* *$} & \multicolumn{2}{|c|}{0.10} \\
\hline
\end{tabular}

Where Ns, * and $* *$ mean non-significant, significant at 5 and $1 \%$ level of probability, respectively.

Table 7. Means of seed yield/fed. (kg /fed') as affected by zinc oxide nanoparticles concentrations, peanut cultivars, and their interaction in 2017 and 2018 seasons.

\begin{tabular}{|c|c|c|c|c|c|c|c|c|}
\hline Season & \multicolumn{4}{|c|}{2017} & \multicolumn{4}{|c|}{2018} \\
\hline \multirow{2}{*}{$\begin{array}{c}\text { Zinc oxide nanopar- } \\
\text { ticles } \\
\text { (ppm) }\end{array}$} & \multicolumn{3}{|c|}{ Cultivars } & \multirow[b]{2}{*}{ Mean } & \multicolumn{3}{|c|}{ Cultivars } & \multirow[b]{2}{*}{ Mean } \\
\hline & $\begin{array}{l}\hat{Z} \\
\text { z }\end{array}$ & 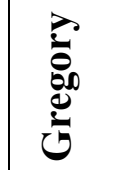 & : & & ż & 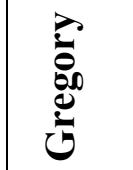 & 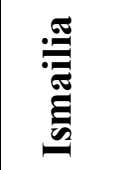 & \\
\hline Control & 544.53 & 522.13 & 533.33 & 533.33 & 515.20 & 488.53 & 506.83 & 503.52 \\
\hline 200 & 542.67 & 538.93 & 542.66 & 541.42 & 503.47 & 492.27 & 497.87 & 497.87 \\
\hline 400 & 598.67 & 589.33 & 576.26 & 588.09 & 639.73 & 632.26 & 621.07 & 631.02 \\
\hline 600 & 611.73 & 596.80 & 570.67 & 588.08 & 690.13 & 645.33 & 643.47 & 659.64 \\
\hline Mean & 574.40 & 561.80 & 555.73 & ---- & 587.13 & 564.60 & 567.30 & ----- \\
\hline F test and R. LSD & \multicolumn{2}{|c|}{ F test } & \multicolumn{2}{|c|}{ R. LSD 0.05} & \multicolumn{2}{|c|}{ F test } & \multicolumn{2}{|c|}{ R. LSD 0.05} \\
\hline ZnO NPs & \multicolumn{2}{|c|}{$* *$} & \multicolumn{2}{|c|}{30.91} & \multicolumn{2}{|r|}{$* *$} & \multicolumn{2}{|c|}{26.20} \\
\hline Cultivars & \multicolumn{2}{|r|}{ 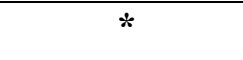 } & \multicolumn{2}{|c|}{11.99} & \multicolumn{2}{|r|}{ Ns } & \multicolumn{2}{|r|}{--} \\
\hline Interaction & \multicolumn{2}{|c|}{ Ns } & \multicolumn{2}{|c|}{---} & \multicolumn{2}{|r|}{ Ns } & \multicolumn{2}{|r|}{--- } \\
\hline
\end{tabular}

Where Ns, * and ** mean non-significant, significant at 5 and $1 \%$ level of probability, respectively. 
Table 8. Means of oil yield/fed. (kg/fed) as affected by zinc oxide nanoparticles concentrations, peanut cultivars and their interaction in 2017 and 2018 seasons.

\begin{tabular}{|c|c|c|c|c|c|c|c|c|}
\hline Season & \multicolumn{4}{|c|}{2017} & \multicolumn{4}{|c|}{2018} \\
\hline \multirow{2}{*}{$\begin{array}{c}\text { Zinc oxide nanopar- } \\
\text { ticles } \\
\text { (ppm) }\end{array}$} & \multicolumn{3}{|c|}{ Cultivars } & \multirow[b]{2}{*}{ Mean } & \multicolumn{3}{|c|}{ Cultivars } & \multirow[b]{2}{*}{ Mean } \\
\hline & $\underset{z}{Z}$ & ל⿺辶一𧰨 & : & & $\underset{z}{\partial}$ & ל⿺辶冋, & : & \\
\hline Control & 258.05 & 254.07 & 266.54 & 259.55 & 233.71 & 225.69 & 232.14 & 230.51 \\
\hline 200 & 258.17 & 250.95 & 270.91 & 260.01 & 234.44 & 248.75 & 241.97 & 241.72 \\
\hline 400 & 289.84 & 308.77 & 287.09 & 295.23 & 322.92 & 298.79 & 306.31 & 309.34 \\
\hline 600 & 291.90 & 298.77 & 284.85 & 291.84 & 327.46 & 322.54 & 315.19 & 321.73 \\
\hline Mean & 274.49 & 278.14 & 277.35 & ---- & 279.63 & 273.94 & 273.90 & $\begin{array}{l}---- \\
\end{array}$ \\
\hline F test and R. LSD & \multicolumn{2}{|c|}{ F test } & \multicolumn{2}{|c|}{ R. LSD 0.05} & \multicolumn{2}{|c|}{ F test } & \multicolumn{2}{|c|}{ R. LSD 0.05} \\
\hline ZnO NPs & \multicolumn{2}{|c|}{$\% *$} & \multicolumn{2}{|c|}{15.67} & \multicolumn{2}{|r|}{$* *$} & \multicolumn{2}{|c|}{12.96} \\
\hline Cultivars & \multicolumn{2}{|c|}{ Ns } & \multicolumn{2}{|r|}{--} & \multicolumn{2}{|r|}{ Ns } & \multicolumn{2}{|r|}{--} \\
\hline Interaction & \multicolumn{2}{|c|}{$* *$} & \multicolumn{2}{|c|}{4.24} & \multicolumn{2}{|r|}{ Ns } & \multicolumn{2}{|r|}{--- } \\
\hline
\end{tabular}

Where Ns, $*$ and $* *$ mean non-significant, significant at 5 and $1 \%$ level of probability, respectively. 